\title{
SYNTHESIS AND BIOLOGICAL EVALUATION OF BIARYL ANALOGS OF ANTITUBULIN COMPOUNDS
}

Camila Santos Suniga Tozatti, Rejane Gonçalves Diniz Khodyuk, Adriano Olimpio da Silva, Edson dos Anjos dos Santos, Marcos Serrou do Amaral e Dênis Pires de Lima*

Centro de Ciências Exatas e Tecnologia, Universidade Federal de Mato Grosso do Sul, Av. Senador Filinto Müller, 1555 , 79074-460 Campo Grande - MS, Brasil

\section{Ernest Hamel}

Screening Technologies Branch, Developmental Therapeutics Program, Division of Cancer Treatment and Diagnosis, National Cancer Institute at Frederick, National Institutes of Health, Frederick, MD 21702, USA

Recebido em 5/1/12; aceito em 1/5/12; publicado na web em 3/8/12

\begin{abstract}
This paper reports the synthesis of methanones and esters bearing different substitution patterns as spacer groups between aromatic rings. This series of compounds can be considered phenstatin analogs. Two of the newly synthesized compounds, $\mathbf{5 a}$ and $\mathbf{5 c}$, strongly inhibited tubulin polymerization and the binding of $\left[{ }^{3} \mathrm{H}\right]$ colchicine to tubulin, suggesting that, akin to phenstatin and combretastatin A-4, they can bind to tubulin at the colchicine site.
\end{abstract}

Keywords: methanones; esters; antitubulin.

\section{INTRODUCTION}

Microtubules are structures present in all eukaryotic cells and play an essential role in the formation of mitotic spindles, required for chromosome separation during cell division. Spindle formation is a dynamic process that involves both the disassembly of interphase microtubules and the reassembly of mitotic microtubules from $\alpha \beta$-tubulin heterodimers. ${ }^{1}$ The fact that microtubules are essential in mitosis has prompted the investigation of substances capable of stabilizing or disrupting them by binding to tubulin subunits. ${ }^{2}$

Combretastatin A-4 (CA-4, Figure 1) - a natural product isolated from the bark of the African tree Combretum caffrum (Combretaceae) - has an excellent affinity for tubulin. ${ }^{3} \mathrm{CA}-4$ has been shown to inhibit cell growth at low concentrations, and its interaction with tubulin is rapid at both 0 and $37^{\circ} \mathrm{C}$, and it also dissociates from tubulin faster than does colchicine (Figure 1). Both CA-4 and ligand CN2, an analog of colchicine (Figure 1), are potent antitubulin agents that act at the colchicine site on $\beta$-tubulin. - $^{4-6}$

A number of studies have addressed the synthesis of analogs bearing different spacer groups between the aromatic rings of CA-4. Many of these analogs were shown to exhibit cytotoxic and antitubulin activities comparable with those of CA-4. ${ }^{5,7}$ Isosteric substitutions of the double-bond spacer in stilbenoids by methylene, ${ }^{8}$ or even by other functions, such as amine and ether, lead to reduction or loss of cytotoxic and antitubulin activities. An $\mathrm{OCH}_{2}$-type ether, however, was found to have antitubulin activity comparable with that of CA-4. ${ }^{7}$ Phenstatin (Figure 1), unexpectedly discovered by Pettit and coworkers in 1998, has lower cytotoxic activity than CA-4, but comparable antitubulin activity. ${ }^{9}$

These apparently paradoxical features have spurred a number of studies on the structural factors that influence biological activity, such as the role of spacer groups and substituent affinity in residues adjacent to the binding site of colchicine. ${ }^{9}$

Since the therapeutic action of any compound is a result of its interaction with biological systems, effectiveness is highly dependent on chemical structure and, therefore, electronic distribution.

The present study describes the synthesis of phenstatin analogs

*e-mail: denis.lima@ufms.br<smiles>COc1cc2c(c(OC)c1OC)-c1ccc(OC)c(=O)cc1C(NC(C)=O)CC2</smiles>

Colchicine<smiles>COc1ccc(/C=C\c2cc(OC)c(OC)c(OC)c2)cc1O</smiles>

CA-4<smiles>COc1ccc(C(=O)c2cc(OC)c(OC)c(OC)c2)cc1O</smiles>

Figure 1. Molecular structure of colchicine, CA-4, CN2, and phenstatin

containing ketones or esters as spacer groups between aromatic rings with different substituents. The newly synthesized compounds were all evaluated for potential effects on tubulin polymerization, and the most active assembly inhibitors were also found to strongly inhibit the binding of tritiated colchicine $\left(\left[{ }^{3} \mathrm{H}\right]\right.$ colchicine $)$, to tubulin.

\section{RESULTS AND DISCUSSION}

\section{Synthesis}

Scheme 1 shows the preparation of methanones $4 \mathbf{a}-\mathbf{d}$ and $5 \mathbf{5 a - c}$ through different reactions. Acid chlorides $\mathbf{2 a - c}$ were obtained by treating benzoic acids 1a-c with thionyl chloride in anhydrous medium - a routine procedure. ${ }^{4}$ Preparation of esters from acid chlorides employed $15 \% \mathrm{NaOH}$. Esters $\mathbf{3} \mathbf{a}$ and $\mathbf{3 b}$ were synthesized by reacting acid chloride 2a with phenol and 4-chlorophenol. Esters 3c-f were produced by reacting benzoyl chloride $2 \mathrm{c}$ with 4-methylphenol, phenol, 4-chlorophenol, and 2-nitrophenol. Esters $\mathbf{3 g}$ and $\mathbf{3 h}$ were directly synthesized by reacting benzoic acid $\mathbf{1 b}$ with phenol and 
4-methylphenol using a mixture of $\mathrm{AlCl}_{3}$ and $\mathrm{ZnCl}_{2} \cdot{ }^{10}$ Overall, good yields were obtained in ester synthesis.

$\alpha$-Hydroxyketones 4a-d (51, 44, 33, and 38\% yields, respectively) were prepared under Fries rearrangement catalyzed by $\mathrm{AlCl}_{3}$ at high temperatures from esters $\mathbf{3 a}, \mathbf{3 b}, \mathbf{3 c}$, and $\mathbf{3 h}$, respectively. ${ }^{11}$ Ketones 5a-c were synthesized by a Friedel-Crafts reaction catalyzed by $\mathrm{AlCl}_{3}{ }^{4}$ Ketone $\mathbf{5 a}$ was obtained by reacting $\mathbf{2 b}$ with anisole (72\% yield); $\mathbf{5 b}$ and $\mathbf{5 c}$ were synthesized by reacting $\mathbf{2} \mathbf{c}$ with toluene and anisole (55 and $80 \%$ yields), respectively.

All reaction intermediates were characterized and/or identified<smiles>[R]c1ccc(OC(=O)c2cc([R])c([R])c([R])c2)c([R])c1</smiles>

$3 \mathrm{~g} \mathrm{R}_{1}=\mathrm{R}_{3}=\mathrm{OCH}_{3} ; \mathrm{R}_{2}=\mathrm{R}_{4}=\mathrm{R}_{5}=\mathrm{H}$ $3 \mathrm{~h} \mathrm{R} \mathrm{R}_{1}=\mathrm{R}_{3}=\mathrm{OCH}_{3} ; \mathrm{R}_{2}=\mathrm{R}_{4}=\mathrm{H} ; \mathrm{R}_{5}=\mathrm{CH}_{3}$

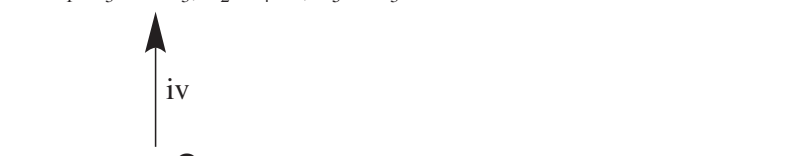

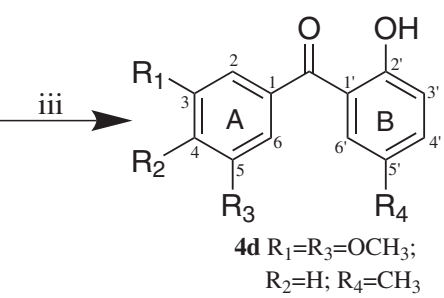

$\begin{aligned} \mathrm{R}_{1} & =\mathrm{R}_{3}=\mathrm{OCH}_{3} \\ \mathrm{R}_{2} & =\mathrm{H} ; \mathrm{R}_{4}=\mathrm{CH}_{3}\end{aligned}$

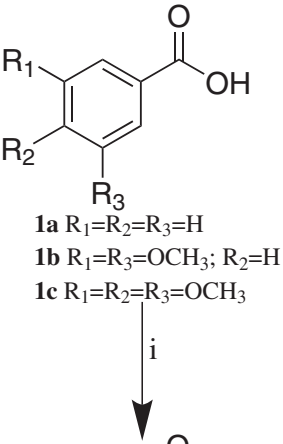

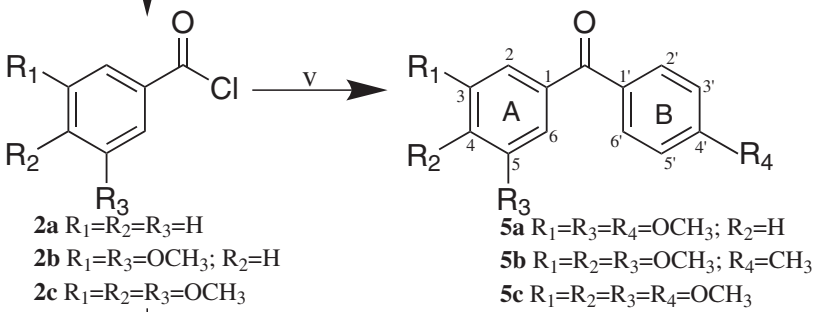<smiles>[R]c1ccc(OC(=O)c2cc([R])c([R])c([R])c2)c(C(=O)O)c1</smiles>

Scheme 1. i) $\mathrm{SOCl}_{2}, \mathrm{CH}_{2} \mathrm{Cl}_{2}, \mathrm{~N}_{2}, \Delta$; ii) $15 \% \mathrm{NaOH}$, phenol/4-chlorophenol/4-methylphenol/2-nitrophenol, r.t.; iii) $\mathrm{AlCl}_{3}, 120-140{ }^{\circ} \mathrm{C}$; iv) $\mathrm{AlCl}_{3}, \mathrm{ZnCl}_{2}$, EtOAc, phenol/4-methylphenol, $\left.\mathrm{N}_{2}, r . t \rightarrow \Delta ; v\right) \mathrm{AlCl}_{3}$, anisole/toluene, $\mathrm{CH}_{2} \mathrm{Cl}_{2}$, $0^{\circ} \mathrm{C} \rightarrow$ r.t. by NMR spectrum analysis, mass spectrometry, and comparison with literature data (see Experimental section).

\section{In vitro antitubulin assays}

The antitubulin activities of the newly synthesized compounds are summarized in Table 1). All compounds were initially evaluated for inhibition of tubulin assembly, but only $\mathbf{5 a}$ and $\mathbf{5 c}$ strongly inhibited the reaction. Therefore, these two compounds were compared with CA-4 and phenstatin for inhibitory effects on colchicine binding. In this assay, tubulin was at $1 \mu \mathrm{M}$, while the $\left[{ }^{3} \mathrm{H}\right]$ colchicine, phenstatin and potential inhibitors were at $5 \mu \mathrm{M}$. As usual, ${ }^{5,7}$ the CA-4 was potently inhibitory (even $1 \mu \mathrm{M} \mathrm{CA}-4$ inhibits colchicine binding by $90 \%$ under the reaction conditions used in the assay). While less inhibitory than CA-4, both $\mathbf{5 a}$ and $\mathbf{5 c}$ were strong inhibitors of colchicine binding, with essentially equivalent activity. The lack of full concordance between the assembly and colchicine binding assays with these two compounds is not fully understood, perhaps reflecting different reaction conditions used in the two assays, but this phenomenon is frequently observed with colchicine site compounds. In terms of structure-activity relationships, the slightly more active $\mathbf{5 c}$ retains the four methoxy groups of the more active phenstatin and CA-4, but lacks the hydroxyl substituent in ring B. The slightly less active 5a lacks the methoxy substituent at position 4 in ring $\mathrm{A}$, as well as the hydroxyl in ring B. Compound $\mathbf{5 b}$, with a large drop in activity, is identical to $\mathbf{5 c}$, except for the loss of the oxygen at position 4 ' in ring B (methyl instead of methoxy substituent).

Table 1. Inhibition of tubulin polymerization and colchicine binding to tubulin

\begin{tabular}{ccc}
\hline Compound & $\begin{array}{c}\text { Inhibition of } \\
\text { polymerization } \\
\mathrm{IC}_{50}\left(\mu \mathrm{M} \pm \mathrm{SD}^{\mathrm{a}}\right)\end{array}$ & $\begin{array}{c}\text { Inhibition of } \\
\text { colchicine binding } \\
\text { \% Inhibition } \pm \mathrm{SD}^{\mathrm{a}}\end{array}$ \\
\hline $\mathbf{5 a}$ & $3.2 \pm 0.08$ & $63 \pm 5$ \\
$\mathbf{5 c}$ & $2.4 \pm 0.2$ & $64 \pm 3$ \\
$\mathbf{4 c}$ & $11 \pm 0.1$ & \\
$\mathbf{4 d}$ & $12 \pm 0.2$ & \\
$\mathbf{5 b}$ & $18 \pm 0.4$ & \\
$\mathbf{3 a - h}$ and $\mathbf{4 a - 4 b}$ & $>40$ (inactive) & \\
CA-4 & $1.2 \pm 0.1$ & $78 \pm 4$ \\
Phenstatin & $1.0 \pm 0.2$ & \\
\hline
\end{tabular}

${ }^{\text {aSD: }}$ standard deviation

The inactivity of 3a-h is in accordance with data previously reported for the ester moiety in analogs of CA-4., ${ }^{42}$ This result may be attributed to changing of the spatial conformation of the rings. Table 1 also shows that ketones with an $\alpha$-carbonyl hydroxyl group (4a-d), as well as compounds $\mathbf{4 a - b}$, were inactive. Three compounds, $\mathbf{4 c}$, $\mathbf{4 d}$, and $\mathbf{5 b}$ were weakly active as tubulin polymerization inhibitors. Compound $\mathbf{4 c}$, however, is structurally identical to the less active $\mathbf{5 b}$, except for an additional hydroxyl group at position 2' in ring $\mathrm{B}$ and the shift of the methoxy substituent from position 4' to 5 ' in ring B. Compound $\mathbf{4 d}$ is nearly equivalent to $\mathbf{4} \mathbf{c}$ in its activity, and $\mathbf{4 d}$ differs from the latter compound in lacking the methoxy substituent at position 4 in the A ring. Since $\mathbf{4 c}$ and $\mathbf{4 d}$ are analogs of $\mathbf{5 c}$ and $\mathbf{5 a}$, respectively, the $\mathrm{B}$ ring changes in the former compounds are clearly deleterious to compound activity.

\section{CONCLUSION}

None of the esters or non-methoxyl-substituted biaryls had antitubulin activity, while the phenstatin-related ketones $\mathbf{5 a}$ and $\mathbf{5 c}$ had significant ability to inhibit tubulin assembly and the binding of 
colchicine to tubulin. These two active ketones had methoxy groups in both aromatic rings (5a and $\mathbf{5 c}$ ). The data indicate the least important methoxy moiety is that at position 4 in ring $A$, and the data also suggest that the hydroxyl group at position $3^{\prime}$ in ring $\mathrm{B}$, present in phenstatin, is important for maximal activity.

\section{SUPPLEMENTARY MATERIAL}

Available at http://quimicanova.sbq.org.br, as a PDF file, with free access.

\section{EXPERIMENTAL}

Silica gel (Merck 230-400 mesh) was used for column chromatography. All solvents and chemicals were of analytical grade. NMR spectra were recorded in $\mathrm{CDCl}_{3}$ solution on a Bruker DPX-300 apparatus. Mass spectra (EI, $70 \mathrm{eV}$ ) were run on a Shimadzu CGMS QP2010 Plus gas chromatography mass spectrometer in direct injection mode. Melting points were recorded on a Uniscience do Brasil, model 498, apparatus.

\section{Synthesis}

General procedure for preparation of acid chlorides $\mathbf{2 a - c}$

A mixture of carboxylic acid (5.57 mmol), $20 \mathrm{~mL}$ of dichloromethane, and thionyl chloride (11.14 mmol), was heated under reflux in a nitrogen atmosphere for $6 \mathrm{~h}$. The solvent was evaporated under vacuum, and acid chlorides $\mathbf{2 a - c}$ were obtained as white solids.

\section{General procedure for preparation of esters $3 a-f$}

The appropriate phenolic compound $(5.57 \mathrm{mmol})$ was added to an aqueous solution of $\mathrm{NaOH}(15 \mathrm{~mL}, 15 \%)$, and the mixture stirred for about $15 \mathrm{~min}$ at room temperature before addition of the appropriate acid chloride $(5.57 \mathrm{mmol})$. After $20 \mathrm{~min}$, the solution was filtered, and the resulting solid was washed with ice-cold water. Products 3a-f were obtained as white powders.

\section{Characterization data of phenyl benzoate (3a)}

Yield 90\% (0.991 g); m.p. $=71-72{ }^{\circ} \mathrm{C}$ (lit., 68-69 $\left.{ }^{\circ} \mathrm{C}\right) ;{ }^{13}{ }^{1} \mathrm{H} \mathrm{NMR}$ (300 MHz; $\left.\mathrm{CDCl}_{3}\right): \delta=7.21$ (H-2' and H-6', d, $\left.J=7.5 \mathrm{~Hz}, 2 \mathrm{H}\right), 7.27$ (H-4', m, 1H), 7.42 (H-3' and H-5', m, 2H), 7.50 (H-3 and H-5, m, 2H), $7.63(\mathrm{H}-4, \mathrm{~m}, 1 \mathrm{H}), 8.20(\mathrm{H}-2$ and $\mathrm{H}-6, \mathrm{~d}, J=7.1 \mathrm{~Hz}, 2 \mathrm{H}) ;{ }^{13} \mathrm{C}$ NMR (75 MHz; $\mathrm{CDCl}_{3}$ ): $\delta=121.7$ (C-2' and C-6'), 125.9 (C-4'), 128.5 (C-3 and C-5), 129.5 (C-3' and C-5'), 129.6 (C-1), 130.1 (C-2 and C-6), 133.5 (C-4), 151.0 (C-1'), 165.1 (C=O); MS (EI) $m / z$ (\%): 198 (4.2), 106 (7.8), 105 (100.0), 94 (0.5), 77 (39.0), 51 (9.1). NMR data were consistent with the literature. ${ }^{14}$

\section{Characterization data of 4-chlorophenyl benzoate $(3 \boldsymbol{b})$}

Yield 90\% (1.16 g); m.p. = 87-88 ${ }^{\circ} \mathrm{C}$ (lit., $\left.87^{\circ} \mathrm{C}\right),{ }^{15}{ }^{1} \mathrm{H}$ NMR $(300$ $\mathrm{MHz} ; \mathrm{CDCl}_{3}$ ): $\delta=7.15$ (H-2' and H-6', d, $\left.J=8.7 \mathrm{~Hz}, 2 \mathrm{H}\right), 7.37(\mathrm{H}-3$ ' and $\mathrm{H}-5$ ', d, $J=8.7 \mathrm{~Hz}, 2 \mathrm{H}), 7.50(\mathrm{H}-3$ and $\mathrm{H}-5, \mathrm{t}, J=7.4 \mathrm{~Hz}, 2 \mathrm{H})$, $7.63(\mathrm{H}-4, \mathrm{t}, J=7.4 \mathrm{~Hz}, 1 \mathrm{H}), 8.17(\mathrm{H}-2$ and $\mathrm{H}-6, \mathrm{~d}, J=7.4 \mathrm{~Hz}, 2 \mathrm{H})$; ${ }^{13} \mathrm{C}$ NMR (75 MHz; $\left.\mathrm{CDCl}_{3}\right): \delta=123.2(\mathrm{C}-2$ ' and C-6'), $128.7(\mathrm{C}-3$ and C-5), 129.2 (C-1), 129.6 (C-3' and C-5'), 130.2 (C-2 and C-6), 131.2 (C-4'), 133.8 (C-4), 149.5 (C-1'), 164.9 (C=O); MS (EI) $\mathrm{m} / \mathrm{z}$ (\%): 232 (0.4), 127 (0.5), 106 (8.0), 105 (100.0), 77 (36.8), 51 (8.1). NMR data were consistent with the literature. ${ }^{16}$

\section{Characterization data of 4-methylphenyl 3,4,5-trimethoxybenzoate} (3c)

Yield 87\% (1.46 g); m.p. $=88-89{ }^{\circ} \mathrm{C} ;{ }^{1} \mathrm{H}$ NMR $(300 \mathrm{MHz}$; $\left.\mathrm{CDCl}_{3}\right): \delta=2.36\left(4^{\prime}-\mathrm{CH}_{3}, \mathrm{~s}, 3 \mathrm{H}\right), 3.92\left(3,4,5-\mathrm{OCH}_{3}, \mathrm{~s}, 9 \mathrm{H}\right), 7.05$
(H-2' and H-6', d, $J=8.1 \mathrm{~Hz}, 2 \mathrm{H}), 7.23$ (H-3' and H-5', d, $J=8.1$ $\mathrm{Hz}, 2 \mathrm{H}), 7.43$ (H-2 and $\mathrm{H}-6, \mathrm{~s}, 2 \mathrm{H}) ;{ }^{13} \mathrm{C} \mathrm{NMR}\left(75 \mathrm{MHz} ; \mathrm{CDCl}_{3}\right)$ : $\delta=20.9\left(4^{\prime}-\mathrm{CH}_{3}\right), 56.3\left(3,5-\mathrm{OCH}_{3}\right), 61.0\left(4-\mathrm{OCH}_{3}\right), 107.4(\mathrm{C}-2$ and C-6), 121.4 (C-2' and C-6'), 124.6 (C-1), 130.0 (C-3' and C-5'), 135.5 (C-4'), 142.7 (C-4), 148.7 (C-1'), 153.0 (C-3 and C-5), $165.0(\mathrm{C}=\mathrm{O})$; MS (EI) m/z (\%): 302 (7.0), 196 (11.0), 195 (100.0), 167 (6.8), 137 (3.9), 107 (2.9), 77 (5.1).

Characterization data of phenyl 3,4,5-trimethoxybenzoate (3d)

Yield 90\% (1.44 g); m.p. $=104-105{ }^{\circ} \mathrm{C}$; ${ }^{1} \mathrm{H}$ NMR $(300 \mathrm{MHz}$; $\left.\mathrm{CDCl}_{3}\right): \delta=3.92\left(3,4,5-\mathrm{OCH}_{3}, \mathrm{~s}, 9 \mathrm{H}\right), 7.18(\mathrm{H}-2$ ' and H-6', d, $J=7.8 \mathrm{~Hz}, 2 \mathrm{H}), 7.27(\mathrm{H}-4$ ', d, $J=7.3 \mathrm{~Hz}, 1 \mathrm{H}), 7.41$ (H-3' and $\mathrm{H}-5$ ', $\mathrm{d}, J=7.8 \mathrm{~Hz}, 2 \mathrm{H}), 7.44(\mathrm{H}-2$ and $\mathrm{H}-6, \mathrm{~s}, 2 \mathrm{H}) ;{ }^{13} \mathrm{C} \mathrm{NMR}(75 \mathrm{MHz}$; $\left.\mathrm{CDCl}_{3}\right): \delta=56.3\left(3,5-\mathrm{OCH}_{3}\right), 60.9\left(4-\mathrm{OCH}_{3}\right), 107.3(\mathrm{C}-2$ and $\mathrm{C}-6)$, 121.7 (C-2' and C-6'), 124.4 (C-1), 125.9 (C-4'), 129.5 (C-3' and C-5'), 142.8 (C-4), 151.0 (C-1'), 153.0 (C-3 and C-5), 164.8 (C=O); MS (EI) $m / z$ (\%): 288 (8.6), 196 (11.0), 195 (100.0), 167 (7.2), 152 (7.7), 77 (4.8), 51 (0.9).

\section{Characterization data of 4-chlorophenyl 3,4,5-trimethoxybenzoate} (3e)

Yield 95\% (1.70 g); m.p. $=91-92{ }^{\circ} \mathrm{C} ;{ }^{1} \mathrm{H}$ NMR $(300 \mathrm{MHz}$; $\left.\mathrm{CDCl}_{3}\right): \delta=3.91\left(3,5-\mathrm{OCH}_{3}, \mathrm{~s}, 6 \mathrm{H}\right), 3.92\left(4-\mathrm{OCH}_{3}, \mathrm{~s}, 3 \mathrm{H}\right), 7.12$ (H-2' and H-6', d, $J=8.7 \mathrm{~Hz}, 2 \mathrm{H}), 7.36$ (H-3' and H-5', d, $J=8.7$ $\mathrm{Hz}, 2 \mathrm{H}), 7.40(\mathrm{H}-2$ and $\mathrm{H}-6, \mathrm{~s}, 2 \mathrm{H}) ;{ }^{13} \mathrm{C} \mathrm{NMR}\left(75 \mathrm{MHz} ; \mathrm{CDCl}_{3}\right)$ : $\delta=56.2\left(3,5-\mathrm{OCH}_{3}\right), 60.9\left(4-\mathrm{OCH}_{3}\right), 107.3(\mathrm{C}-2$ and $\mathrm{C}-6), 123.1$ (C-2' and C-6'), 123.9 (C-1), 129.5 (C-3' and C-5'), 131.2 (C-4'), 142.8 (C-4), 149.3 (C-1'), 153.0 (C-3 and C-5), $164.5(\mathrm{C}=\mathrm{O})$; MS (EI) $\mathrm{m} / \mathrm{z}(\%): 322$ (2.9), 196 (11.2), 195 (100.0), 167 (7.2), 152 (7.6), 137 (4.9), 122 (4.3).

\section{Characterization data of 2-nitrophenyl 3,4,5-trimethoxybenzoate (3f)}

Yield 80\% (1.48 g); m.p. $=143-144{ }^{\circ} \mathrm{C}$; ${ }^{1} \mathrm{H}$ NMR $(300 \mathrm{MHz}$; $\left.\mathrm{CDCl}_{3}\right): \delta=3.91\left(3,5-\mathrm{OCH}_{3}, \mathrm{~s}, 6 \mathrm{H}\right), 3.93\left(4-\mathrm{OCH}_{3}, \mathrm{~s}, 3 \mathrm{H}\right), 7.37$ (H-4', m, 1H), 7.42 (H-2 and H-6, s, 2H), 7.43 (H-6', m, 1H), 7.68 (H-5', m, 1H), 8.11 (H-3', d, $J=8.3 \mathrm{~Hz}, 1 \mathrm{H}) ;{ }^{13} \mathrm{C}$ NMR $(75 \mathrm{MHz}$; $\left.\mathrm{CDCl}_{3}\right): \delta=56.2\left(3,5-\mathrm{OCH}_{3}\right), 60.9\left(4-\mathrm{OCH}_{3}\right), 107.6(\mathrm{C}-2$ and $\mathrm{C}-6)$, 123.1 (C-1), 125.2 (C-6'), 125.8 (C-3'), 126.6 (C-4'), 134.6 (C-5'), 141.6 (C-2'), 143.2 (C-4), 144.2 (C-1'), 153.0 (C-3 and C-5), 163.8 $(\mathrm{C}=\mathrm{O})$; MS (EI) $m / z$ (\%): 333 (6.4), 195 (100.0), 152 (9.2), 137 (7.0).

\section{General procedure for preparation of esters $3 g$ and $\mathbf{3 h}$}

A mixture of carboxylic acid $\mathbf{1 b}(5.57 \mathrm{mmol})$ and anhydrous $\mathrm{AlCl}_{3}$ $(0.20 \mathrm{mmol})$ in $20 \mathrm{~mL}$ of ethyl acetate was stirred continuously at room temperature. After $5 \mathrm{~min}$, the corresponding phenol (5.57 $\mathrm{mmol})$ and anhydrous $\mathrm{ZnCl}_{2}$ were added to the reaction mixture, which was heated and stirred under reflux in a nitrogen atmosphere for $8 \mathrm{~h}$. Subsequently, ice-cold $1 \mathrm{M} \mathrm{HCl}$ was added to the mixture and the reaction mixture transferred to a separatory funnel and extracted with ethyl acetate $(3 \times 25 \mathrm{~mL})$. The combined organic extracts were washed with water $(3 \times 25 \mathrm{~mL})$ and dried with $\mathrm{Na}_{2} \mathrm{SO}_{4}$. Evaporation of the organic solvent under reduced pressure furnished a crude ester. After filtration through silica gel using ethyl acetate:hexane (1:5) as the solvent system, product $\mathbf{3} \mathbf{g}$ was obtained as a yellow oil and product $\mathbf{3 h}$ as a white solid.

\section{Characterization data of phenyl 3,5-dimethoxybenzoate (3g)}

Yield 70\% (1.00 g); oil; ${ }^{1} \mathrm{H}$ NMR (300 MHz; $\left.\mathrm{CDCl}_{3}\right): \delta=3.85$ $\left(3,5-\mathrm{OCH}_{3}, \mathrm{~s}, 6 \mathrm{H}\right), 6.70(\mathrm{H}-4, \mathrm{t}, J=2.3 \mathrm{~Hz}, 1 \mathrm{H}), 7.19(\mathrm{H}-2$ ' and H-6', d, $J=7.9 \mathrm{~Hz}, 2 \mathrm{H}), 7.27$ (H-4', $\mathrm{m}, 1 \mathrm{H}), 7.32(\mathrm{H}-2$ and $\mathrm{H}-6, \mathrm{~d}, J=2.3$ $\mathrm{Hz}, 2 \mathrm{H}), 7.42(\mathrm{H}-3$ ' and H-5', t, $J=7.9 \mathrm{~Hz}, 2 \mathrm{H}) ;{ }^{13} \mathrm{C}$ NMR $(75 \mathrm{MHz}$; $\left.\mathrm{CDCl}_{3}\right): \delta=55.6\left(3,5-\mathrm{OCH}_{3}\right), 106.4(\mathrm{C}-4), 107.7$ (C-2 and C-6), 121.7 
(C-2' and C-6'), 125.9 (C-4'), 129.5 (C-3' and C-5'), 131.4 (C-1), 150.9 (C-1'), 160.8 (C-3 and C-5), 164.9 (C=O); MS (EI) $\mathrm{m} / z(\%)$ : 258 (11.2), 166 (9.7), 165 (100.0), 137 (28.9), 122 (16.4), 107 (9.9), 94 (2.5), 77 (7.4), 51 (2.7).

\section{Characterization data of 4-methylphenyl 3,5-dimethoxybenzoate (3h)}

Yield 85\% (1.28 g); m.p. $=74-76{ }^{\circ} \mathrm{C} ;{ }^{1} \mathrm{H}$ NMR $(300 \mathrm{MHz}$; $\left.\mathrm{CDCl}_{3}\right): \delta=2.37\left(4^{\prime}-\mathrm{CH}_{3}, \mathrm{~s}, 3 \mathrm{H}\right), 3.84\left(3,5-\mathrm{OCH}_{3}, \mathrm{~s}, 6 \mathrm{H}\right), 6.70(\mathrm{H}-$ $4, \mathrm{t}, J=2.1 \mathrm{~Hz}, 1 \mathrm{H}), 7.06(\mathrm{H}-2$ ' and H-6', d, $J=7.7 \mathrm{~Hz}, 2 \mathrm{H}), 7.28$ (H-3' and $\mathrm{H}-5$ ', d, $J=7.7 \mathrm{~Hz}, 2 \mathrm{H}), 7.32(\mathrm{H}-2$ and $\mathrm{H}-6, \mathrm{~d}, J=2.1$ $\mathrm{Hz}, 2 \mathrm{H}) ;{ }^{13} \mathrm{C}$ NMR $\left(75 \mathrm{MHz} ; \mathrm{CDCl}_{3}\right): \delta=21.3\left(4^{\prime}-\mathrm{CH}_{3}\right), 55.6(3,5-$ $\left.\mathrm{OCH}_{3}\right), 106.3$ (C-4), 107.6 (C-2 and C-6), 118.6-129.2 (C-2', C-6', C-3' and C-5'), 131.4 (C-1), 139.7 (C-4'), 150.9 (C-1'), 160.7 (C-3 and C-5), $165.0(\mathrm{C}=\mathrm{O})$; MS (EI) $\mathrm{m} / \mathrm{z}(\%): 272$ (12.0), 165 (100.0), 137 (27.4), 122 (13.9), 107 (8.7), 92 (2.1), 77 (7.0).

\section{General procedure for preparation of $\alpha$-hydroxyketones $4 a-4 d$}

Using a typical procedure, the corresponding ester $(2.57 \mathrm{mmol})$ was thoroughly mixed with anhydrous $\mathrm{AlCl}_{3}(3.74 \mathrm{mmol})$ and heated to $120-140^{\circ} \mathrm{C}$ for $25 \mathrm{~min}$, after which the mixture was treated with an ice-cold aqueous $10 \%$ solution of $\mathrm{HCl}$ and subsequently vacuum filtered. The solid residue was ground and extracted with an aqueous $10 \%$ solution of $\mathrm{NaOH}(3 \times 30 \mathrm{~mL})$. The solution was then neutralized with aqueous $10 \% \mathrm{HCl}$. The product was extracted with ether $(3 \times 30 \mathrm{~mL})$, and the combined organic phases were washed with a saturated $\mathrm{NaCl}$ solution. Drying over anhydrous $\mathrm{Na}_{2} \mathrm{SO}_{4}$ followed by ether evaporation furnished the corresponding $\alpha$-hydroxyketones namely, $\mathbf{4 a}$ as a light yellow liquid, $\mathbf{4 b}$ as a dark yellow solid, and $\mathbf{4 c}$ and $\mathbf{4 d}$ as white solids.

\section{Characterization data of 2-hydroxybenzophenone (4a)}

Yield 51\% (0.259 g); liquid; $\left.{ }^{1} \mathrm{H} \mathrm{NMR} \mathrm{(300} \mathrm{MHz;} \mathrm{CDCl}_{3}\right): \delta=6.85$ (H-5', m, 1H), 7.05 (H-3', d, $J=8.4$ Hz, 1H), 7.45 (H-4', m, 1H), 7.48 (H-6', m, 1H), 7.54 (H-3 and H-5, m, 2H), $7.57(\mathrm{H}-4, \mathrm{~m}, 1 \mathrm{H})$, $7.65(\mathrm{H}-2$ and $\mathrm{H}-6, \mathrm{~m}, 2 \mathrm{H}) ; 12.0(\mathrm{O}-\mathrm{H}){ }^{13} \mathrm{C} \mathrm{NMR}\left(75 \mathrm{MHz} ; \mathrm{CDCl}_{3}\right)$ : $\delta=118.4\left(\mathrm{C}^{-3}{ }^{\prime}\right), 118.7$ (C-5'), 119.1 (C-1'), 128.3 (C-3 and C-5), 129.2 (C-2 and C-6), 131.9 (C-6'), 133.6 (C-4), 136.3 (C-4'), 137.9 (C-1), 163.2 (C-2'), 201.6 (C=O); MS (EI) m/z (\%): 198 (60.3), 121 (62.5), 105 (30.6), 93 (16.0), 77 (46.6). NMR data were consistent with the literature. ${ }^{17}$

\section{Characterization data of 5-chloro-2-hydroxybenzophenone (4b)}

Yield 44\% (0.262 g); m.p. $=98-99{ }^{\circ} \mathrm{C}$ (lit., 96-97 $\left.{ }^{\circ} \mathrm{C}\right){ }^{18}{ }^{1} \mathrm{H}$ NMR (300 MHz; $\left.\mathrm{CDCl}_{3}\right): \delta=7.02(\mathrm{H}-3$ ', d, $J=8.8 \mathrm{~Hz}, 1 \mathrm{H}), 7.43(\mathrm{H}-4$ ', $\mathrm{dd}, J=8.8 \mathrm{~Hz}, J=2.5 \mathrm{~Hz}, 1 \mathrm{H}), 7.50(\mathrm{H}-6, \mathrm{~m}, 1 \mathrm{H}), 7.54(\mathrm{H}-3$ and $\mathrm{H}-5, \mathrm{~m}, 2 \mathrm{H}), 7.60(\mathrm{H}-4, \mathrm{~m}, 1 \mathrm{H}), 7.66(\mathrm{H}-2$ and $\mathrm{H}-6, \mathrm{~m}, 2 \mathrm{H}), 11.8$ $(\mathrm{O}-\mathrm{H}) ;{ }^{13} \mathrm{C}$ NMR $\left(75 \mathrm{MHz} ; \mathrm{CDCl}_{3}\right): \delta=119.7(\mathrm{C}-1$ ') 120.0 (C-3'), 123.3 (C-5'), 128.5 (C-3 and C-5), 129.1 (C-2 and C-6), 132.3 (C-6'), 132.3 (C-4), 136.1 (C-4'), 137.2 (C-1), 161.6 (C-2'), 200.6 (C=O); MS (EI) $m / z$ (\%): 232 (59.0), 231 (100.0), 196 (2.6), 155 (32.9), 126 (13.5), 105 (57.3), 77 (81.7), 51 (24.8).

\section{Characterization data of 2'-hydroxy-5'-methyl-3,4,5- \\ trimethoxybenzophenone (4c)}

Yield 33\% (0.256 g); liquid; ${ }^{1} \mathrm{H}$ NMR (300 MHz; $\left.\mathrm{CDCl}_{3}\right): \delta=$ $2.26\left(5^{\prime}-\mathrm{CH}_{3}, \mathrm{~s}, 3 \mathrm{H}\right), 3.88\left(3,5-\mathrm{OCH}_{3}, \mathrm{~s}, 6 \mathrm{H}\right), 3.93\left(4-\mathrm{OCH}_{3}, \mathrm{~s}, 3 \mathrm{H}\right)$, $6.90(\mathrm{H}-2$ and H-6, s, 2H), $6.97(\mathrm{H}-3$ ', $\mathrm{d}, J=8.3 \mathrm{~Hz}, 1 \mathrm{H}), 7.31(\mathrm{H}-$ 4', dd, $J=8.3 \mathrm{~Hz}, J=1.3 \mathrm{~Hz}, 1 \mathrm{H}), 7.42(\mathrm{H}-6$ ', d, $J=1.3 \mathrm{~Hz}, 1 \mathrm{H})$; ${ }^{13} \mathrm{C}$ NMR $\left(75 \mathrm{MHz} ; \mathrm{CDCl}_{3}\right): \delta=20.5\left(5^{\prime}-\mathrm{CH}_{3}\right), 56.3\left(3,5-\mathrm{OCH}_{3}\right)$, $61.0\left(4-\mathrm{OCH}_{3}\right), 106.9$ (C-2 and C-6), $118.2(\mathrm{C}-3$ ') 118.8 (C-1'), 127.7 (C-1), 133.0 (C-6'), 137.2 (C-4'), 138.4 (C-5'), 141.5 (C-4), 152.9 (C-3 and C-5), 161.0 (C-2'), 200.4 (C=O); MS (EI) $\mathrm{m} / z(\%)$ :
302 (6.8), 196 (12.1), 195 (100.0), 152 (9.0), 137 (7.4), 122 (5.6), 92 (3.7), 77 (11.9).

Characterization data of 2-hydroxy-5-methyl-3,,5'dimethoxybenzophenone (4d)

Yield 38\% (0.265 g); m.p. $=90-91{ }^{\circ} \mathrm{C} ;{ }^{1} \mathrm{H}$ NMR $(300 \mathrm{MHz}$; $\left.\mathrm{CDCl}_{3}\right): \delta=2.35\left(5^{\prime}-\mathrm{CH}_{3}, \mathrm{~s}, 3 \mathrm{H}\right), 3.81\left(3,5-\mathrm{OCH}_{3}, \mathrm{~s}, 6 \mathrm{H}\right), 6.63(\mathrm{H}$ $-4, \mathrm{t}, J=2.1 \mathrm{~Hz}, 1 \mathrm{H}), 6.66\left(\mathrm{H}_{-} 4^{\prime}, \mathrm{d}, J=8.1 \mathrm{~Hz}, 1 \mathrm{H}\right), 6.74(\mathrm{H}-2$ and H-6, d, $J=2.1 \mathrm{~Hz}, 2 \mathrm{H}), 6.85$ (H-6', s, 1H), 7.50 (H-3', d, $J=8.1 \mathrm{~Hz}$, $1 \mathrm{H}) ;{ }^{13} \mathrm{C} \mathrm{NMR}\left(75 \mathrm{MHz} ; \mathrm{CDCl}_{3}\right): \delta=22.0\left(5^{\prime}-\mathrm{CH}_{3}\right), 55.6\left(3,5-\mathrm{OCH}_{3}\right)$, 103.8 (C-4), 106.8 (C-2 and C-6), 116.8 (C-1'), 118.4 (C-3'), 120.0 (C-6'), 133.4 (C-4'), 139.9 (C-1), 148.2 (C-5'), 160.5 (C-3 and C-5), 163.4 (C-2'), 200.8 (C=O); MS (EI) $\mathrm{m} / \mathrm{z}(\%): 272$ (42.8), 271 (22.2), 241 (100.0), 135 (59.2), 107 (17.9), 77 (34.0), 51 (6.4).

\section{General procedure for preparation of ketones $\mathbf{5 a - c}$}

Anhydrous $\mathrm{AlCl}_{3}$ (2.0 mmol) was added to a well-stirred solution of the appropriate acid chloride $(2.0 \mathrm{mmol})$ and the appropriate aromatic compound $(2.0 \mathrm{mmol})$ at $0{ }^{\circ} \mathrm{C}$ in dichloromethane $(25 \mathrm{~mL})$. The mixture was stirred as it warmed to room temperature. After $6 \mathrm{~h}$, the resulting dark reaction mixture was poured into ice-cold aqueous $5 \% \mathrm{HCl}(20$ $\mathrm{mL}$ ), and the organic phase was separated. The aqueous phase was extracted with dichloromethane $(30 \mathrm{~mL})$, and the combined organic phases were washed with a saturated $\mathrm{NaHCO}_{3}$ solution. The solvent was evaporated under reduced pressure, and the resulting material was subjected to flash chromatography using ethyl acetate:hexane (1:5) as the eluent. Products 5a-c were obtained as yellowish solids.

\section{Characterization data of 3,4',5-trimethoxybenzophenone (5a)}

Yield $72 \%$ (0.391 g); m.p. $=89-91{ }^{\circ} \mathrm{C}$ (lit., 90-91 $\left.{ }^{\circ} \mathrm{C}\right) ;{ }^{19}{ }^{1} \mathrm{H}$ NMR $\left(300 \mathrm{MHz} ; \mathrm{CDCl}_{3}\right): \delta=3.80\left(3,5-\mathrm{OCH}_{3}, \mathrm{~s}, 6 \mathrm{H}\right), 3.86\left(4^{\prime}-\mathrm{OCH}_{3}, \mathrm{~s}\right.$, $3 \mathrm{H}), 6.63(\mathrm{H}-4, \mathrm{t}, J=2.3 \mathrm{~Hz}, 1 \mathrm{H}), 6.85(\mathrm{H}-2$ and $\mathrm{H}-6, \mathrm{~d}, J=2.3 \mathrm{~Hz}$, 2H), 6.93 (H-3' and H-5', d, $J=8.7 \mathrm{~Hz}, 2 \mathrm{H}), 7.82$ (H-2' and H-6', $\mathrm{d}, J=8.7 \mathrm{~Hz}, 2 \mathrm{H}) ;{ }^{13} \mathrm{C} \mathrm{NMR}\left(75 \mathrm{MHz} ; \mathrm{CDCl}_{3}\right): \delta=55.5\left(4^{\prime}-\mathrm{OCH}_{3}\right)$, $55.6\left(3,5-\mathrm{OCH}_{3}\right), 104.2(\mathrm{C}-4), 107.5(\mathrm{C}-2$ and $\mathrm{C}-6), 113.5(\mathrm{C}-3$ ' ' and C-5'), 130.0 (C-1'), 132.5 (C-2' and C-6'), 140.2 (C-1), 160.5 (C-3 and C-5), 163.3 (C-4'), $195.1(\mathrm{C}=\mathrm{O})$; MS (EI) $\mathrm{m} / \mathrm{z}(\%): 272$ (44.1), 257 (4.7), 241 (2.4), 135 (100.0), 107 (11.6), 77 (13.4). NMR data were consistent with the literature. ${ }^{19}$

Characterization data of 4'-methyl-3,4,5-trimethoxybenzophenone (5b)

Yield 55\% (0.314 g); m.p. $=87-88{ }^{\circ} \mathrm{C} ;{ }^{1} \mathrm{H}$ NMR $(300 \mathrm{MHz}$; $\left.\mathrm{CDCl}_{3}\right): \delta=2.42\left(4^{\prime}-\mathrm{CH}_{3}, \mathrm{~s}, 3 \mathrm{H}\right), 3.85\left(3,5-\mathrm{OCH}_{3}, \mathrm{~s}, 6 \mathrm{H}\right), 3.91$ (4$\left.\mathrm{OCH}_{3}, \mathrm{~s}, 3 \mathrm{H}\right), 7.03$ (H-2 and $\left.\mathrm{H}-6, \mathrm{~s}, 2 \mathrm{H}\right), 7.26(\mathrm{H}-3$ ' and $\mathrm{H}-5$ ', $\mathrm{d}, J=$ $8.0 \mathrm{~Hz}, 2 \mathrm{H}), 7.70$ (H-2' and H-6', d, $J=8.0 \mathrm{~Hz}, 2 \mathrm{H}) ;{ }^{13} \mathrm{C} \mathrm{NMR}(75$ $\left.\mathrm{MHz} ; \mathrm{CDCl}_{3}\right): \delta=21.6\left(4^{\prime}-\mathrm{CH}_{3}\right), 56.3\left(3,5-\mathrm{OCH}_{3}\right), 60.9\left(4-\mathrm{OCH}_{3}\right)$, 107.6 (C-2 and C-6), 128.9 (C-2' and C-6'), 130.1 (C-3' and C-5'), 132.9 (C-1), 135.0 (C-1'), 141.8 (C-4), 143.0 (C-4'), 152.8 (C-3 and C-5), 195.5 (C=O); MS (EI) m/z (\%): 286 (100.0), 271 (37.6), 243 (27.7), 195 (36.4), 119 (50.4), 91 (35.4).

Characterization data of 3,4,4',5-tetramethoxybenzophenone (5c)

Yield $80 \%$ (0.483 g); m.p. $=70-72{ }^{\circ} \mathrm{C}$ (lit., $\left.72-73{ }^{\circ} \mathrm{C}\right) ;{ }^{4}{ }^{1} \mathrm{H}$ NMR $\left(300 \mathrm{MHz} ; \mathrm{CDCl}_{3}\right): \delta=3.85\left(3,5-\mathrm{OCH}_{3}, \mathrm{~s}, 6 \mathrm{H}\right), 3.86\left(4\right.$ ' $-\mathrm{OCH}_{3}, \mathrm{~s}$, $3 \mathrm{H}), 3.90\left(4-\mathrm{OCH}_{3}, \mathrm{~s}, 3 \mathrm{H}\right), 6.95(\mathrm{H}-3$ ' and $\mathrm{H}-5$ ', $\mathrm{d}, J=8.7 \mathrm{~Hz}, 2 \mathrm{H})$, 6.99 (H-2 and H-6, s, 2H), 7.80 (H-2' and H-6', d, $J=8.7 \mathrm{~Hz}, 2 \mathrm{H})$; ${ }^{13} \mathrm{C}$ NMR (75 MHz; $\left.\mathrm{CDCl}_{3}\right): \delta=55.4\left(4 '-\mathrm{OCH}_{3}\right), 56.3\left(3,5-\mathrm{OCH}_{3}\right)$, $60.9\left(4-\mathrm{OCH}_{3}\right), 107.4$ (C-2 and C-6), 113.5 (C-3' and C-5'), 130.2 (C-1), 132.3 (C-2' and C-6'), 133.3 (C-1'), 141.6 (C-4), 152.8 (C-3 and C-5), 163.1 (C-4'), 194.6 (C=O); MS (EI) $\mathrm{m} / \mathrm{z}$ (\%): 302 (100.0), 287 (19.2), 259 (29.9), 195 (17.0), 135 (70.3), 107 (11.7), 77 (15.9), 51 (1.3). NMR data were consistent with the literature. ${ }^{4}$ 


\section{Tubulin assays (in vitro)}

Tubulin assembly and $\left[{ }^{3} \mathrm{H}\right]$ colchicine binding assays were performed with electrophoretically homogenous bovine brain tubulin. The assembly assay was performed with $10 \mu \mathrm{M}(1.0 \mathrm{mg} / \mathrm{mL})$ tubulin in $0.8 \mathrm{M}$ monosodium glutamate $(\mathrm{pH} 6.6$ with $\mathrm{HCl}$ in a $2.0 \mathrm{M}$ stock solution), $0.4 \mathrm{mM}$ GTP, and 4\% (v/v) dimethyl sulfoxide (as compound solvent). Tubulin and varying compound concentrations were preincubated without GTP for $15 \mathrm{~min}$ at $30{ }^{\circ} \mathrm{C}$, samples were placed on ice, and GTP was added. The samples were transferred to $0{ }^{\circ} \mathrm{C}$ cuvettes for measurement in Beckman DU7400 and DU7500 recording spectrophotometers equipped with electronic temperature controllers. After baselines were established at $350 \mathrm{~nm}$, the temperature was jumped to $30{ }^{\circ} \mathrm{C}$ (less than $1 \mathrm{~min}$ ), and sample turbidity was followed for $20 \mathrm{~min}$. The $\mathrm{IC}_{50}$ was the compound concentration at which the turbidity reading at $20 \mathrm{~min}$ was reduced by $50 \%$ relative to a control reaction mixture without compound. ${ }^{20}$

The colchicine binding assay was performed as described elsewhere. ${ }^{21}$ Samples contained 1.0 $\mu \mathrm{M}$ tubulin and 5.0 $\mu \mathrm{M}$ each of $\left[{ }^{3} \mathrm{H}\right]$ colchicine (tritiated colchicine from Perkin Elmer, Boston MA, NET189250UC, the specific activity of the supplied material is 60$87 \mathrm{Ci}(2220-3219 \mathrm{GBq}) / \mathrm{mmol})$ and the potential inhibitor. The samples were incubated for $10 \mathrm{~min}$ at $37^{\circ} \mathrm{C}$, a time at which binding in control reaction mixtures is $40-60 \%$ complete. The incubation conditions used stabilized tubulin for long periods (up to 3 days at $37^{\circ} \mathrm{C}$ ). ${ }^{21}$

CA-4, a potent inhibitor of colchicine binding and tubulin assembly, was generously provided by Dr. G. R. Pettit of Arizona State University (USA) and served as a positive control in the assays.

\section{ACKNOWLEDGMENTS}

The authors wish to thank CAPES (Brazil) and FUNDECT-MS (Brazil) for scholarship and financial support and PROPP-UFMS for the support and infrastructure provided.

\section{REFERENCES}

1. Ducki, S.; Mackenzie, G.; Lawrence, N. J.; Snyder, J.; J. Med. Chem. 2005, 48, 457.

2. O’Boyle, N. M.; Greene, L. M.; Bergin, O.; Fichet, J. B.; McCabe, T.; Lloyd, D. G.; Zisterer, D. M.; Meegan, M. J.; Bioorg. Med. Chem. 2011, 19, 2306.

3. Lin, C. M.; Singh, S. B.; Chu, P. S.; Dempcy, R. O.; Schmidt, J. M.; Pettit, G. R.; Hamel, E.; Mol. Pharmacol. 1988, 34, 200.

4. Cushman, M.; Nagarathnam, D.; Gopal, D.; He, H. M.; Lin, C. M.; Hamel, E.; J. Med. Chem. 1992, 35, 2293.

5. Lin, C. M.; Ho, H. H.; Pettit, G. R.; Hamel, E.; Biochemistry 1989, 28, 6984.

6. Cormier, A.; Marchand, M.; Ravelli, R. B. G.; Knossow, M.; Gigant, B.; Embo Reports 2008, 9, 1101.

7. Lawrence, N. J.; Rennison, D.; Woo, M.; McGown, A. T.; Hadfield, J. A.; Bioorg. Med. Chem. Lett. 2001, 11, 51 .

8. Getahun, Z.; Jurd, T. L.; Chu, P. S.; Lin, C. M.; Hamel, E.; J. Med. Chem. 1992, 35, 1058.

9. Pettit, G. R.; Toki, B.; Herald, D. L.; Verdier-Pinard, P.; Boyd, M. R.; Hamel, E.; Pettit, R. K.; J. Med. Chem. 1998, 41, 1688.

10. Roy, H. N.; Mamun, A. H.; Synth. Commun. 2006, 36, 2975.

11. Khanum, S. A.; Shashikanth, S.; Sudha, B. S.; Science Asia 2003, 29, 383.

12. Nam, N. H.; Curr. Med. Chem. 2003, 10, 1697.

13. Doering, W. V. E.; Dorfman, E.; J. Am. Chem. Soc. 1953, 75, 5595.

14. Bradamante, S.; Pagani, G. A.; J. Org. Chem. 1980, 45, 114.

15. Hayashi, M.; Journal für Praktische chemie (Leipzig) 1929, 123, 289.

16. Neuvonen, H.; Neuvonen, K.; Pasanen, P.; J. Org. Chem. 2004, 69, 3794.

17. Lampert, H.; Mikenda, W.; Karpfen, A.; Kahlig, H.; J. Phys. Chem. A 1997, 101, 9610 .

18. Chakravarti, D.; Bera, C. B.; J. Indian Chem. Soc. 1944, 21, 109.

19. Pettit, G. R.; Grealish, M. P.; Jung, M. K.; Hamel, E.; Pettit, R. K.; Chapuis, J. C.; Schmidt, J. M.; J. Med. Chem. 2002, 45, 2534.

20. Hamel, E.; Cell Biochem. Biophys. 2003, 38, 1.

21. Hamel, E.; Lin, C. M.; Biochim. Biophys. Acta 1981, 675, 226. 


\section{SYNTHESIS AND BIOLOGICAL EVALUATION OF BIARYL ANALOGS OF ANTITUBULIN COMPOUNDS}

Camila Santos Suniga Tozatti, Rejane Gonçalves Diniz Khodyuk, Adriano Olimpio da Silva, Edson dos Anjos dos Santos, Marcos Serrou do Amaral e Dênis Pires de Lima*

Centro de Ciências Exatas e Tecnologia, Universidade Federal de Mato Grosso do Sul, Av. Senador Filinto Müller, 1555, 79074-460 Campo Grande - MS, Brasil

Ernest Hamel

Screening Technologies Branch, Developmental Therapeutics Program, Division of Cancer Treatment and Diagnosis, National Cancer Institute at Frederick, National Institutes of Health, Frederick, MD 21702, USA

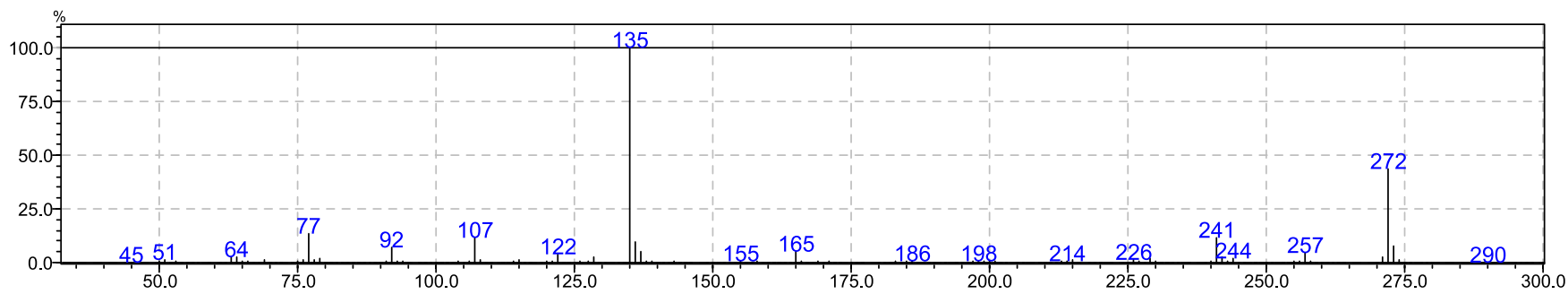

Figure 1S. EI-MS spectrum of 5 a
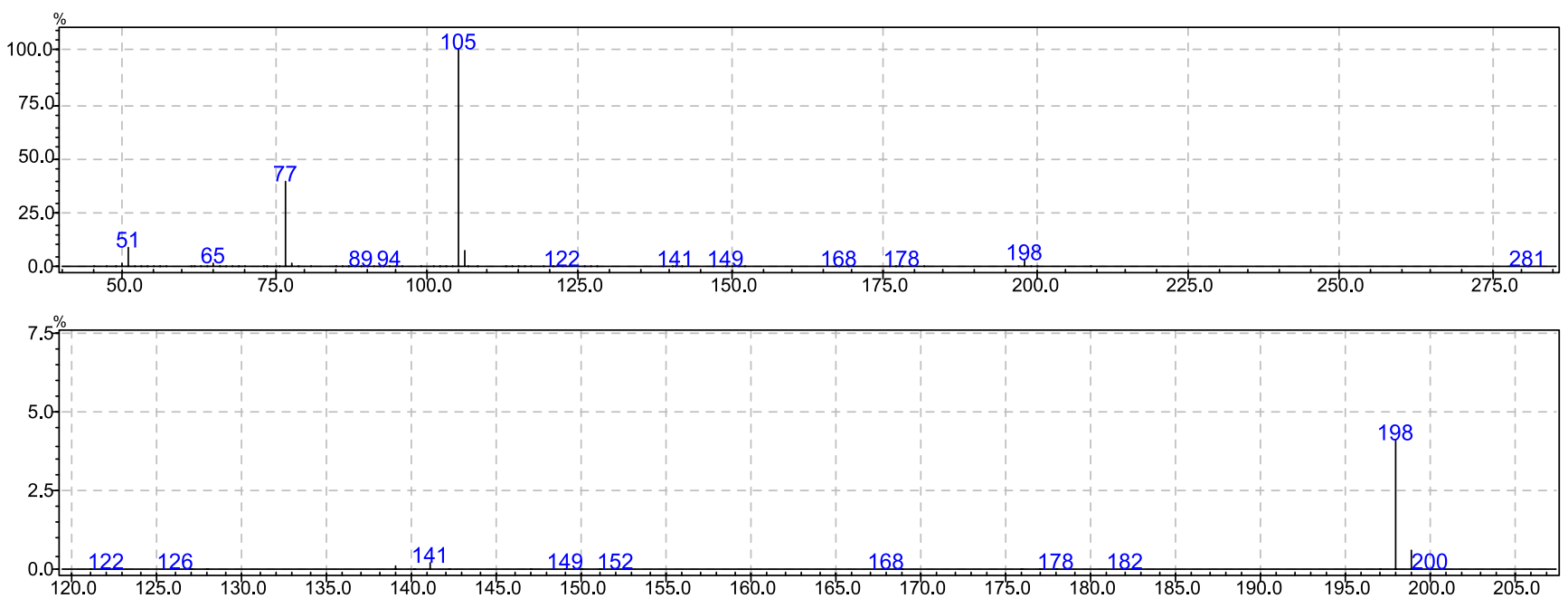

Figure 2S. EI-MS spectrum of $\mathbf{3 a}$ 

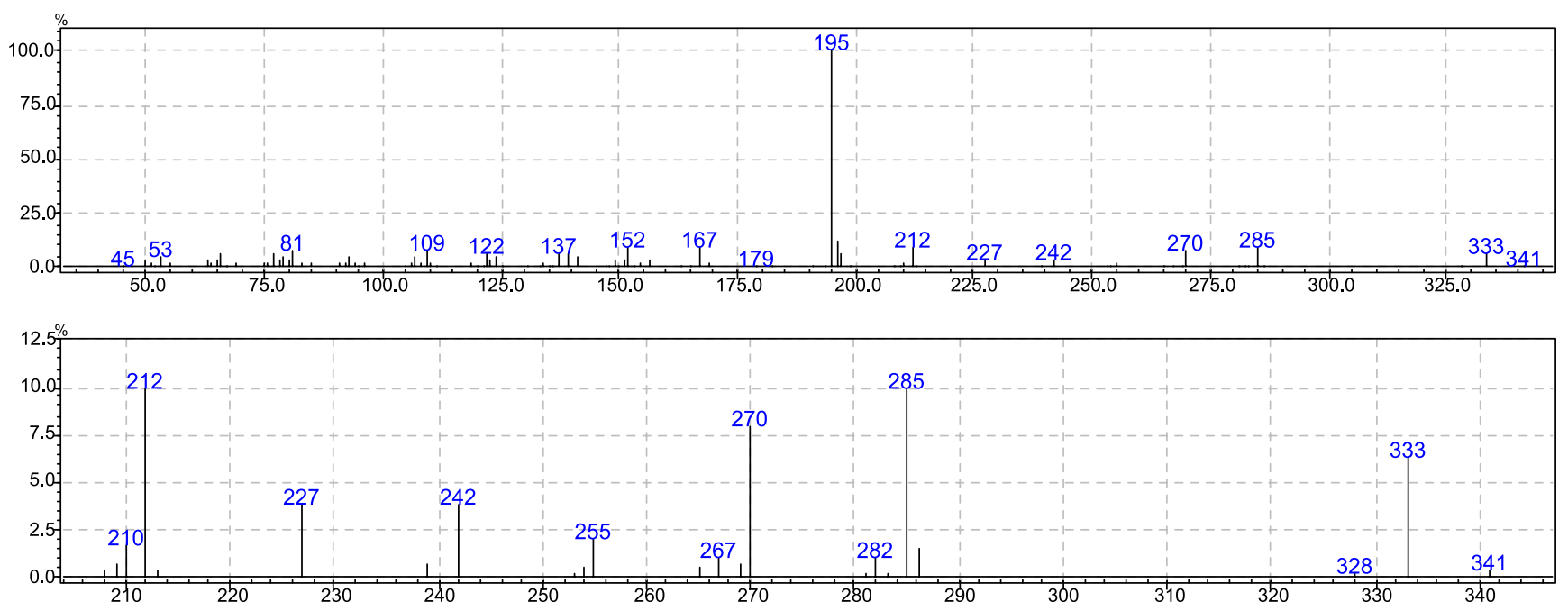

Figure 3S. EI-MS spectrum of $\mathbf{3 f}$
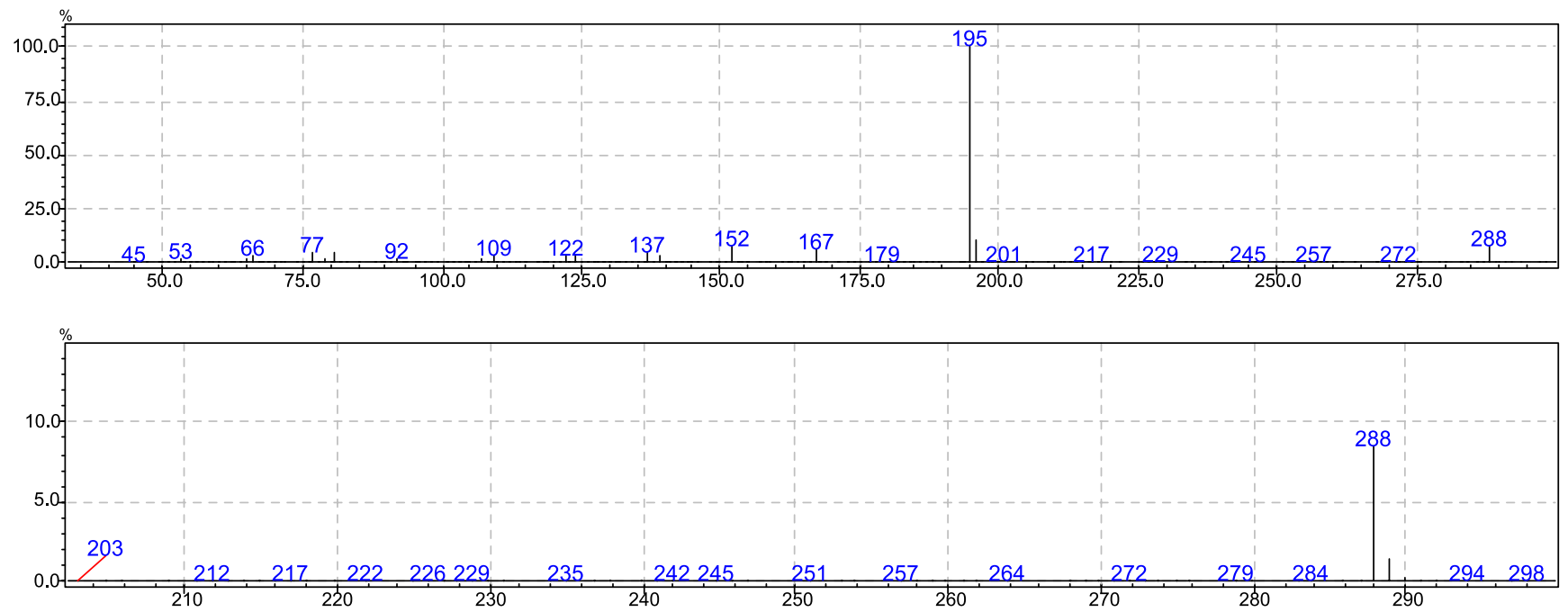

Figure 4S. EI-MS spectrum of $\mathbf{3 d}$

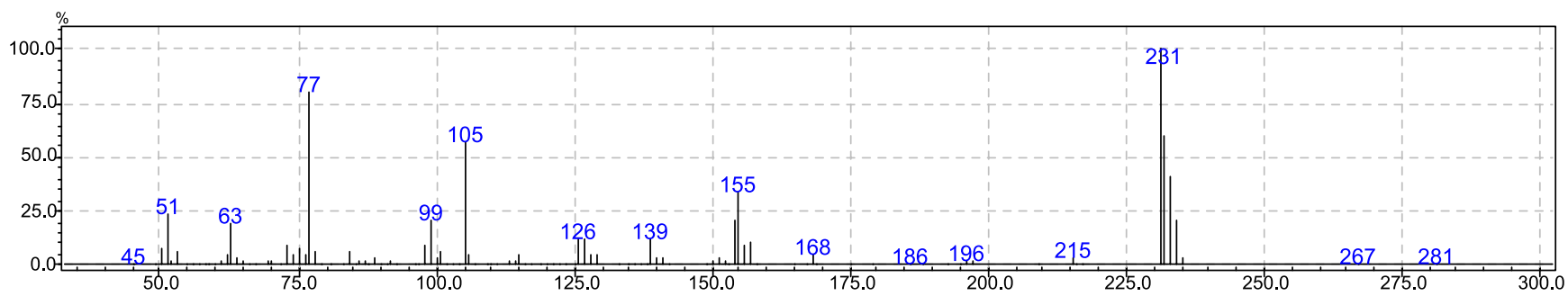

Figure 5S. EI-MS spectrum of $4 b$ 

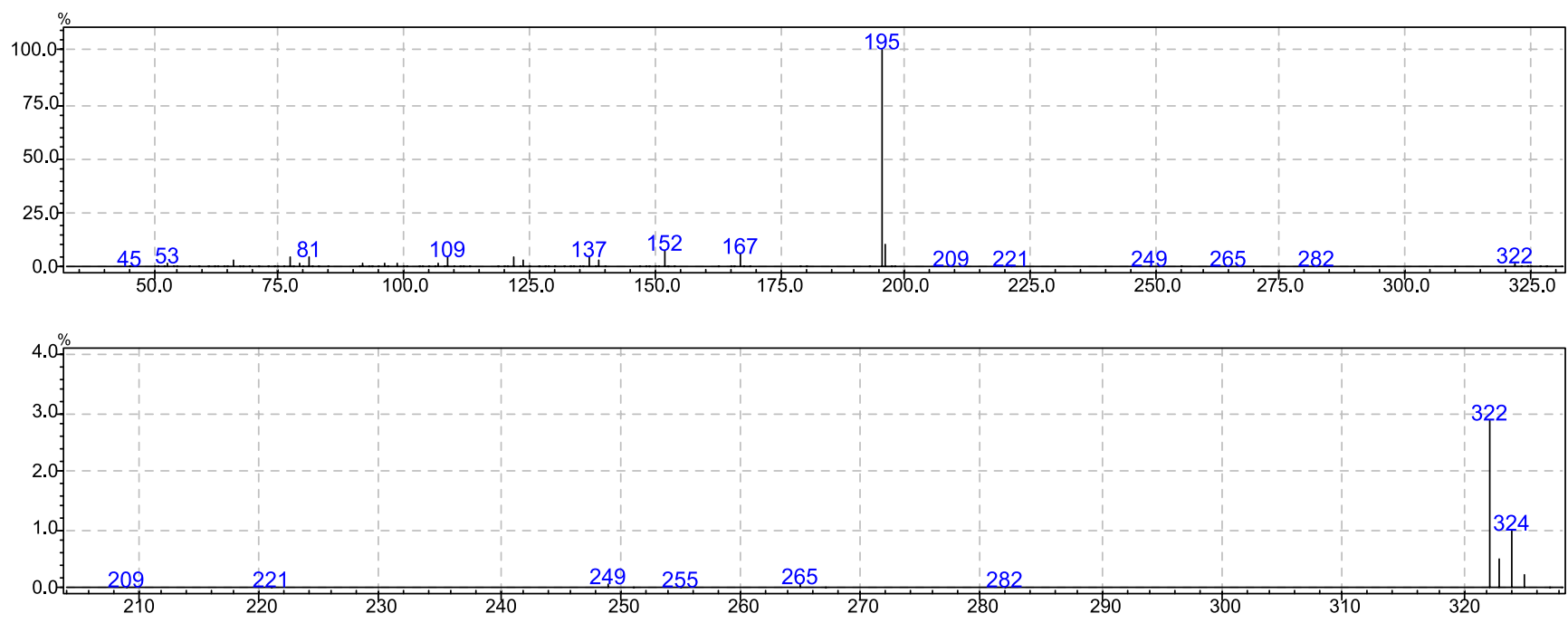

Figure 6S. EI-MS spectrum of $3 \boldsymbol{e}$

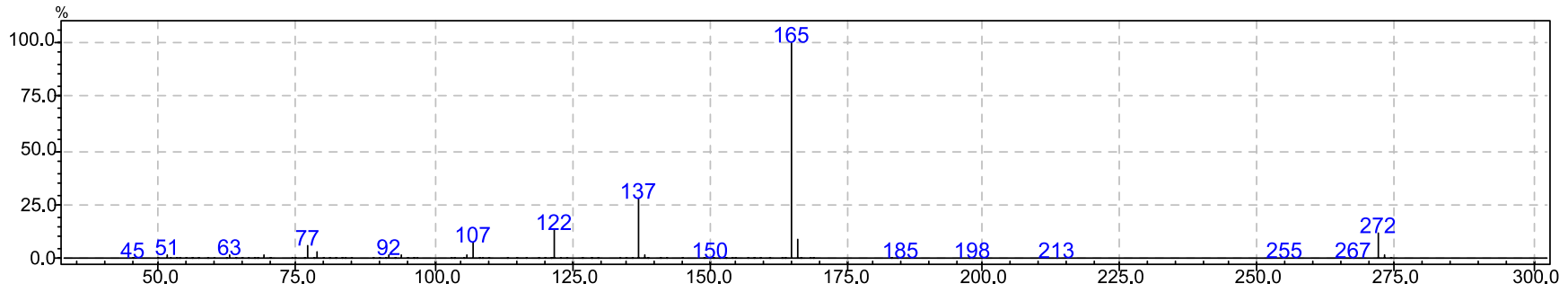

Figure 7S. EI-MS spectrum of $3 \mathbf{h}$

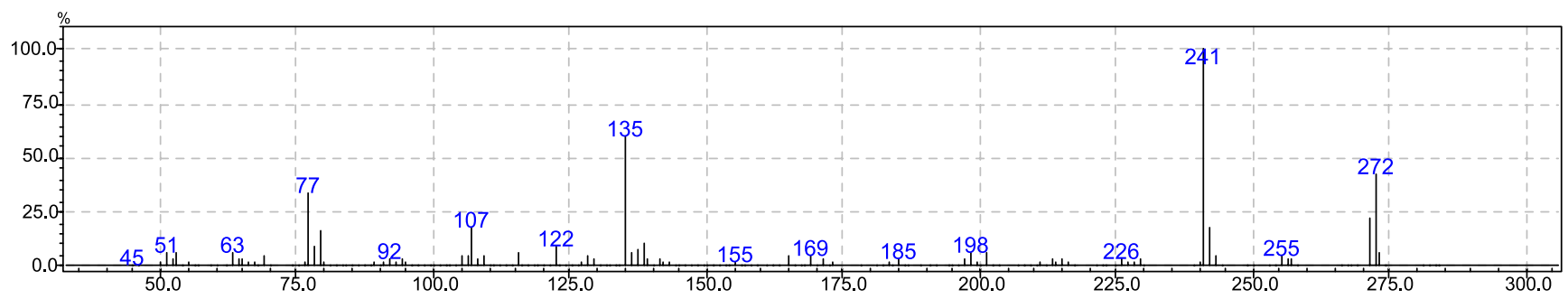

Figure 8S. EI-MS spectrum of $\mathbf{4 d}$

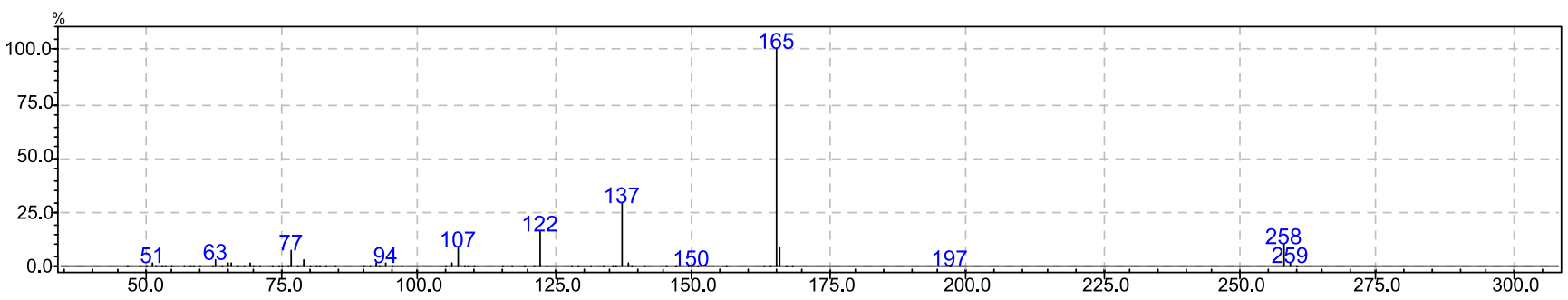

Figure 9S. EI-MS spectrum of $3 g$ 


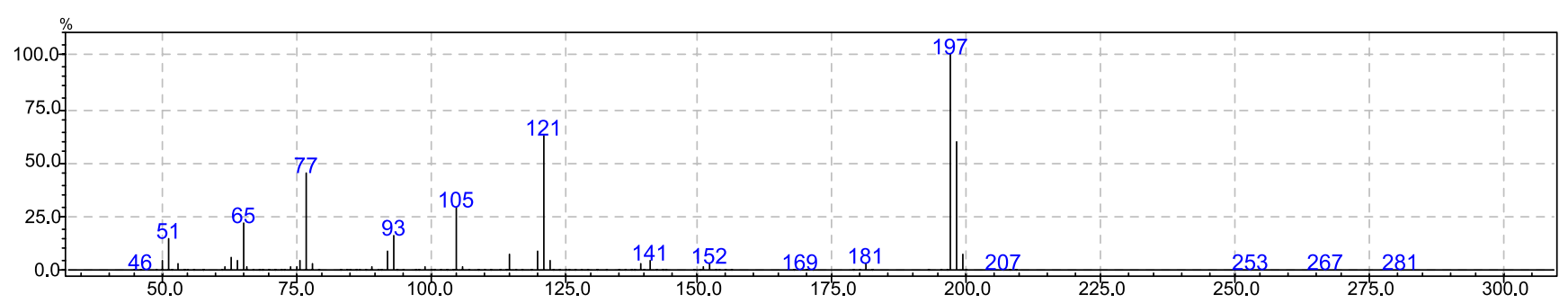

Figure 10S. EI-MS spectrum of $4 a$

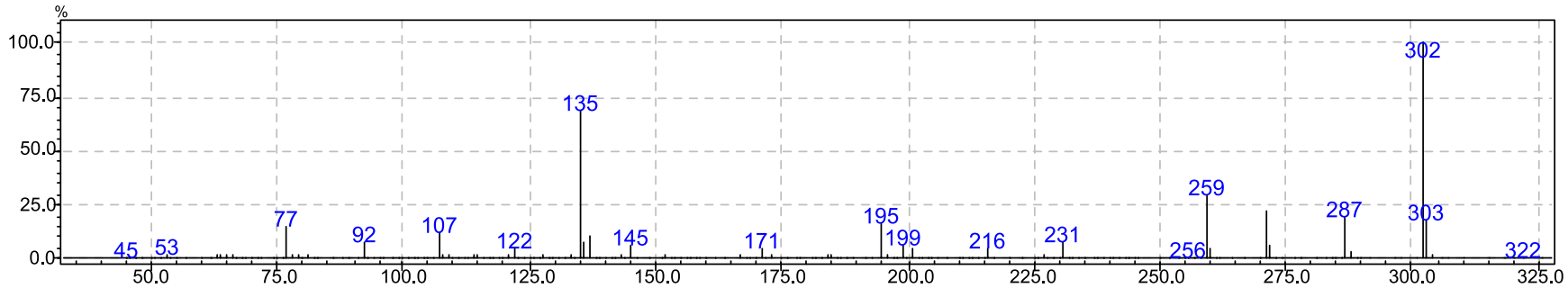

Figure 11S. EI-MS spectrum of 5c
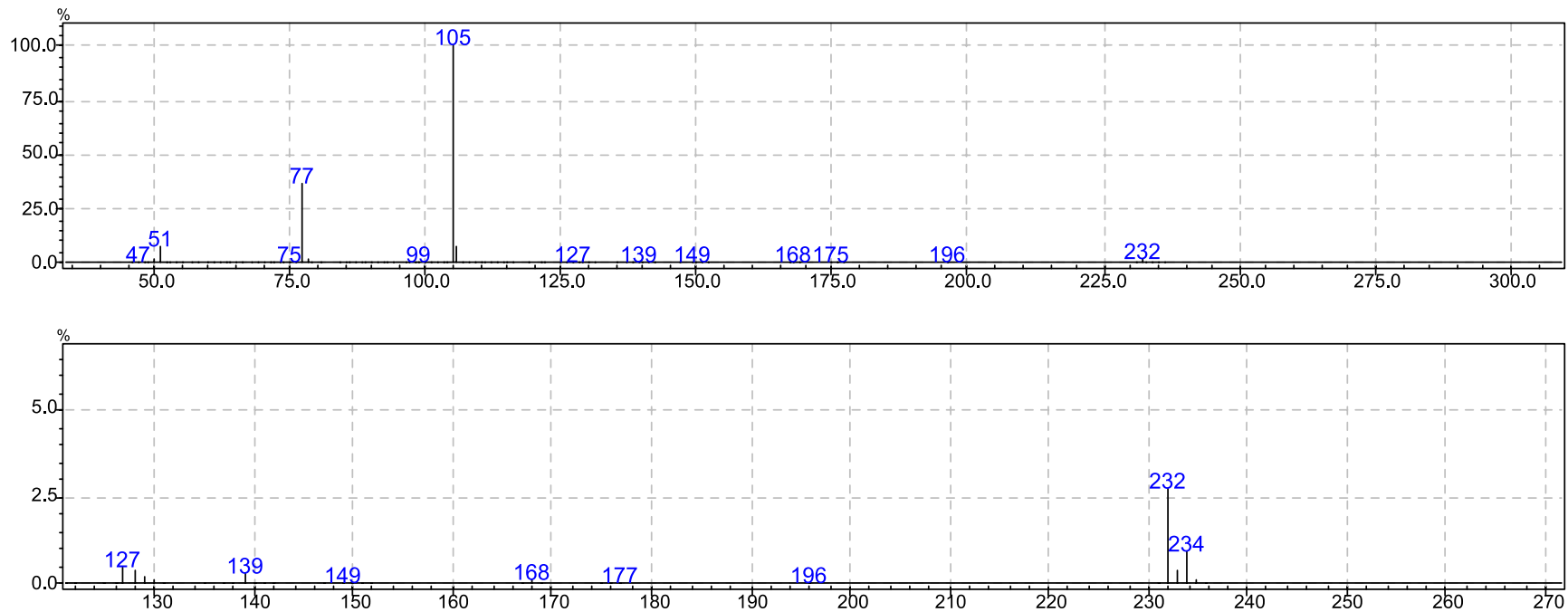

Figure 12S. EI-MS spectrum of $3 b$ 



Figure 13S. EI-MS spectrum of $3 c$

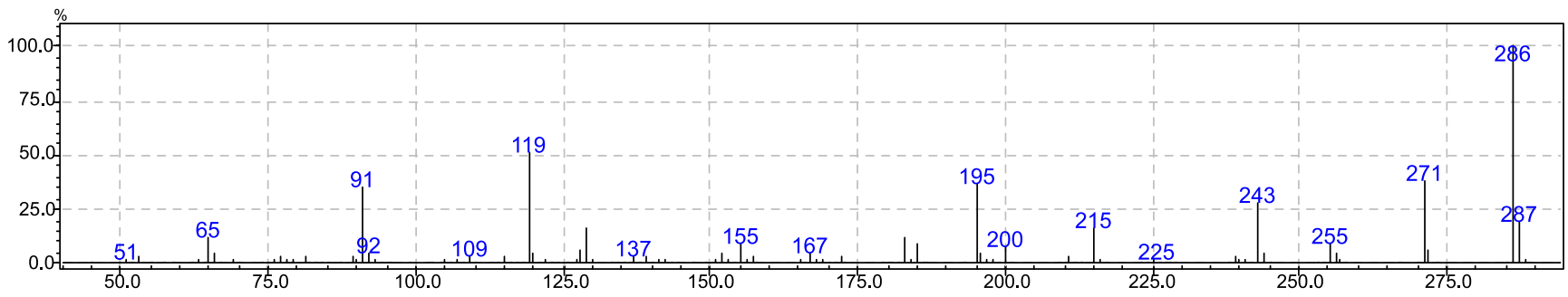

Figure 14S. EI-MS spectrum of $5 \mathrm{~b}$
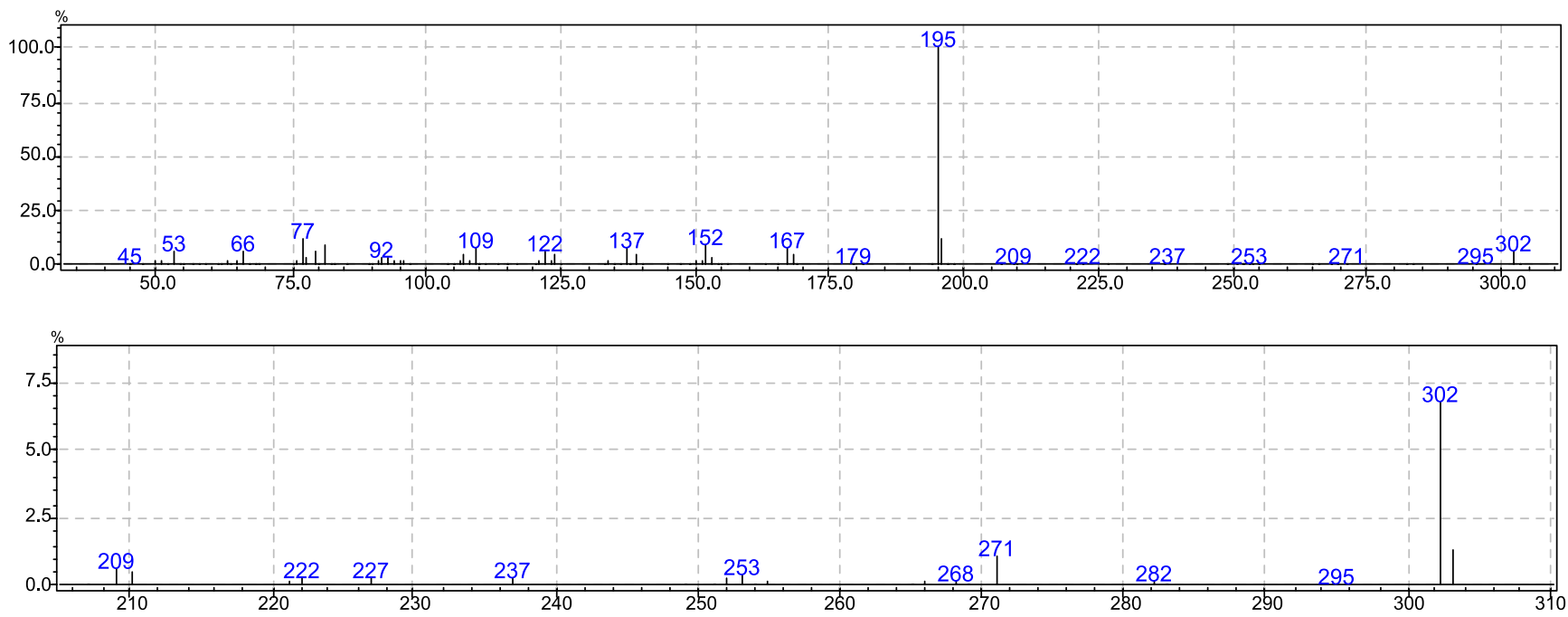

Figure 15S. EI-MS spectrum of $4 c$ 